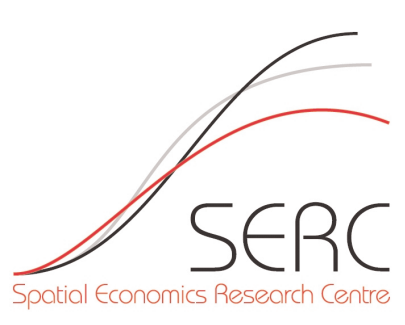

SERC DISCUSSION PAPER 34

\title{
The Impact of Immigration on
} Occupational Wages: Evidence from Britain

Stephen Nickell (SERC, CEP, Nuffield College, University of Oxford) Jumana Saleheen (Bank of England)

October 2009 
This work was part of the research programme of the independent UK Spatial Economics Research Centre funded by the Economic and Social Research Council (ESRC), Department for Business, Enterprise and Regulatory Reform (BERR), the Department for Communities and Local Government (CLG), and the Welsh Assembly Government. The support of the funders is acknowledged. The views expressed are those of the authors and do not represent the views of the funders.

(C) S. Nickell and J. Saleheen, submitted 2009 


\title{
The Impact of Immigration on Occupational Wages: Evidence from Britain
}

\author{
Stephen Nickell* and Jumana Saleheen**
}

October 2009

* SERC, CEP, Nuffield College, University of Oxford

${ }^{* *}$ Bank of England

Acknowledgements

The views expressed in this paper are those of the authors, and not necessarily those of the Bank of England. The work in this paper was largely undertaken while Jumana Saleheen was on leave from the Bank of England. We would like to thank Bob Triest, Simon Price, Sara Lemos, Alan Manning, Katharine Neiss, Kenneth Turnbull and Yolanda Kodrzycki. 


\begin{abstract}
$\underline{\text { Abstract }}$
This paper asks whether immigration to Britain has had any impact on average wages. There seems to be a broad consensus among academics that the share of immigrants in the workforce has little or no effect on the pay rates of the indigenous population. But the studies in the literature have typically not refined their analysis by breaking it down into different occupational groups. In this paper we find that once the occupational breakdown is incorporated into a regional analysis of immigration in Britain, the immigrant-native ratio has a significant, small, negative impact on average wages. Closer examination reveals that the biggest impact is in the semi/unskilled services sector. This finding accords well with intuition and anecdote, but does not seem to have been recorded previously in the empirical literature.
\end{abstract}

Keywords: Immigration, occupation, wages JEL Classifications: J6 


\section{Introduction}

The rise in immigration experienced in the United Kingdom over the past 10 years is widely believed by the general public and policymakers to have had large effects on the labour market in general and wages in particular. ${ }^{1}$ The stereotype of the Polish plumber-used widely as a symbol of cheap labour-encapsulates the commonly held belief that immigration in Britain has pushed down wages in the most affected jobs. This anecdote will obviously mean more to local residents, but a flavour of this sentiment is captured by the following newspaper extract:

Since 2004 an estimated one million Poles have settled in Britain, taking advantage of the higher wages British employers were prepared to pay. They became so much a part of the country's life that Tesco, Asda and Sainsbury's - as well as innumerable small local shops-started stocking Polish food and drink, and libraries began to stock books and newspapers in Polish....

...Polish builders, with a reputation for working long hours at a fraction of the price local workers charge, have spent four years forcing their British rivals to raise their game.

The Times Newspaper

February 16, 2008

However, the balance of the research on this issue suggests that the share of immigrants in the workforce has had little or no impact on the pay rates of the indigenous population. Nevertheless, there is a continuing controversy, exemplified by Borjas (2003) and Card (2005).

In an earlier paper, Card (1990) examined the impact of the Mariel Boatlift of Cubans into the Miami labour market and found little impact on the wages of natives. Borjas (2003) argues that such an analysis gives a misleading impression because regional labour markets are not self contained. Thus, as immigrants move into a region, natives move out, thereby attenuating local wage effects. So he considers the impact of immigrants on wages in national age/education groups and finds a significant impact on wages in the United States. An immigrant inflow of 10 percent of the labour force lowers the wages of natives by 3 or 4 percent.

\footnotetext{
${ }^{1}$ Its importance for monetary policy is highlighted in a speech by the Governor of the Bank of England, King (2007).
} 
But further research that takes account of native mobility is unable to confirm the Borjas (2003) results. For example, Card (2005), in an analysis of U.S. cities, finds first that increases of immigrants into localities have generated significant rises in the proportion of low-skilled workers (high school dropouts) and second, that these large shifts in the proportions of the lowskilled have had minimal effects on the low-skill wage relative to their effect on the higher-skill wage. ${ }^{2}$ Ottaviano and Peri (2008) also find a much smaller impact of immigration on native wages than that reported in Borjas (2003). Evidence for the United Kingdom is consistent with the findings of Card (2005), suggesting that the impact of immigration on the wages of natives is minimal (see Dustmann et al. (2005) and Manacorda et al. (2006), for example).

Much of the research in this area has concentrated on looking for wage effects of immigration among the low-skilled, where skill levels are defined in terms of education. Unfortunately, however, the measurement of the education levels of migrants is often very tricky because of the difficulty of comparing education qualifications across countries. Furthermore, for a variety of reasons, many immigrants who come to the United Kingdom with high qualification levels work in low-skill occupations. This may tend to corrupt an analysis that depends on using education levels to partition the data.

So here we take a different approach, segmenting the labour market by occupation. One advantage of this approach is that it focuses the analysis on the various groups in the labour market, such as plumbers, agricultural workers, nurses, waiters, etc., which have been the subject of much of the public discussion.

Some occupations see a very heavy influx of immigrants. For example, in Britain, over 30 percent of health professionals (for example, doctors and dentists) are immigrants, compared with around 5 percent of those in skilled agricultural trades (for example, farmers and gardeners). A priori, it seems unlikely that a substantive rise in immigration in a particular

\footnotetext{
2 This would appear to be at variance with standard economics based on supply and demand. The most convincing explanation is that there is a weaker adoption of advanced technology, which is complementary to skilled labour, in the presence of larger numbers of the unskilled. This would offset the wage effects of shifts in the proportion of unskilled workers. See Lewis $(2004,2005)$ and Beaudry et al. (2006), for evidence in favour of this explanation.
} 
region and occupation has had absolutely no impact on pay in that region and occupation. Our purpose is to find out more about this.

While there is a great deal of anecdotal discussion on the impact of immigration in specific occupations like agriculture and construction, we feel it would be helpful to present some harder data on this subject. For this reason, the first part of this paper is about occupations. We consider some facts about which occupations tend to see a higher share of immigrants, how this has changed over time, and what has happened to pay in these occupations.

The paper then moves on to a more formal empirical analysis of the relationship between migration and wages. It finds that once the occupational breakdown is incorporated into a regional analysis of immigration, the immigrant-native ratio has a significant, small, negative impact on the average occupational wage rates of the regions.

It is worth making one final important comment on how the analysis in this paper differs from previous research. This paper considers the impact of immigration on average occupational wages, rather than the impact of immigration on native average occupational wages - which is the focus in much of the existing literature on immigration.

\section{Immigration across occupations: some facts}

Immigration to the United Kingdom has risen dramatically over the past decade. This can be seen clearly from the charts below. Chart 1 shows that according to the official migration statistics, the net inflow of immigrants to the United Kingdom each year has risen from around 50,000 individuals in 1995 to around 200,000 in 2006. The gross outflow has grown as well, but by increasingly less than the gross inflow, and as a result, the net inflow of immigrants has risen dramatically since the mid 1990s. Chart 2 shows how immigrants-defined as foreign-born workers - have become a larger share of the U.K. working age population. Having been stable at around 8 percent between 1984 and 1995, it has grown to nearly 12 percent by 2006 (Chart 2). The chart also shows that the share of "new" immigrants - those who arrived in the previous two years - has also increased since 1995. 


Chart 1: Immigration into and out of the
United Kingdom

This rise in immigration to the United Kingdom in recent years has been well documented in past studies. But very little has been said about the occupations in which immigrants end up. In this section, we explore the key facts about immigration across occupations. In particular, we document which occupations attract the most immigrants and whether this has changed over time. We also document the trends in wages in the different occupations.

To consider how immigration and wages have changed in each occupation one needs a consistent definition of occupations over time. Since the standard occupational classification changed from SOC 1990 to SOC 2000 at the turn of the century, it is necessary to devise a consistent classification over the time period we consider in this paper, 1992-2006. We do this 
by transforming the SOC 1990 codes into SOC 2000 codes. More details are given in the data appendix.

\subsection{Immigration across occupations}

Which occupations attract the most immigrants? Chart 3 shows the ratio of immigrants to natives in each broadly defined occupation group-measured at the SOC 2000 1-digit level. It shows that the immigrant-native ratio varies rather modestly across broad occupations. It is highest for professional workers (for example, engineers), associate professional workers (for example, science and IT technicians) and those in elementary occupations (for example, cleaners, and labourers). It is lowest among skilled tradesmen (for example, plumbers and electricians) and administrative occupations. In other words, there is a slight tendency for immigrants to be predominant in jobs at the top end of the occupational classification (or highskill jobs) and those at the bottom end of the occupational classification (or low-skill jobs) with fewer in the middle-so that Chart 3 traces out a shallow U-shaped pattern. This reflects the fact that there are many different types of immigrants who come to the United Kingdom. For example, some immigrants come to the United Kingdom having already secured a high-skill job, while others come in search of work and a better standard of living, but end up in occupations at the very bottom end of the occupational distribution, possibly because they lack knowledge of the local labour market and face language difficulties. 


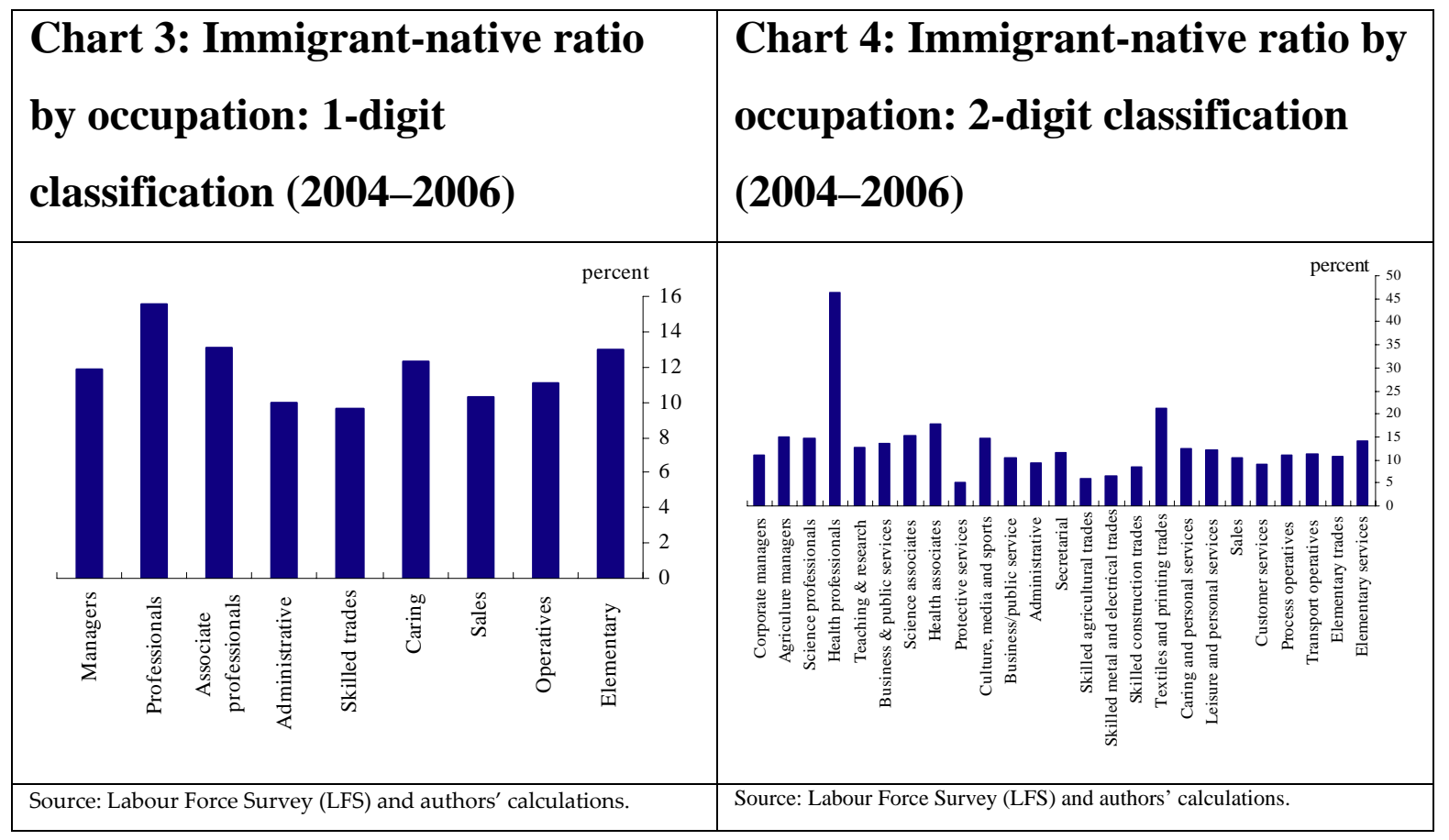

Chart 4 shows the immigrant-native ratio at a more detailed, 2-digit level. The picture is now one of greater variability, with no strong patterns. A very high proportion of U.K. health professionals are immigrants, and very few immigrants work in protective services (for example as firemen).

Earlier it was noted that overall immigration to the United Kingdom has risen rapidly since the middle of the 1990s. An important question here is whether that rise has affected all occupations proportionately or has been more heterogeneous.

Chart 5 shows the immigrant-native ratio in each occupation for three time periods, 1992-94, 1998-00, and 2004-06. A shallow, U-shaped pattern is evident for all three periods: the ratio is highest among professional and elementary workers and lowest for those in skilled trades. It is also evident that the immigrant-native ratio has risen for all occupations over time. Importantly, however, the rise has been greatest in elementary (low-skill) occupations. For example, the immigrant-native ratio for managers grew by 2 percentage points between 1992-94 
and 2004-06, whereas it grew by 5 percentage points for elementary workers over the same period.

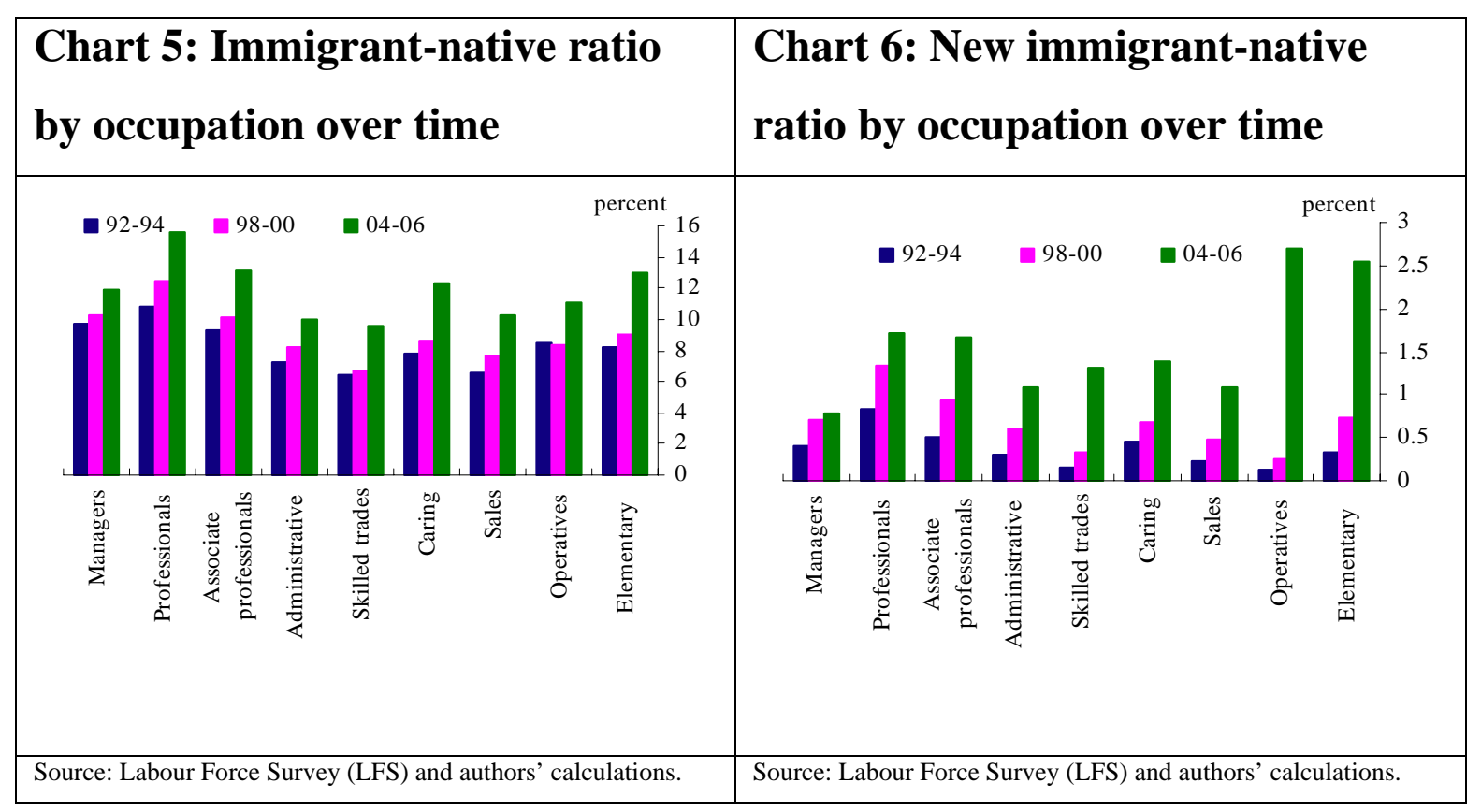

The fact that immigration has risen by proportionately more in lower-skill occupations, particularly in elementary and operatives occupations, is clearer from Chart 6 . This chart reports the ratio of "new" immigrations to natives, where "new" immigrants are defined as those immigrants who entered the United Kingdom in the past two years. During the periods 1992-94 and 1998-00, the new immigrant-native ratios for elementary workers and operatives were among the lowest, but in 2004-06 they were among the highest. In other words, a larger fraction of new immigrants enter low-skill occupations now than in the past. The new immigrant-native ratios in the professional and associate professional occupations were among the highest in 1992-94, and although they remained high in recent years, they are no longer the highest. These changes in structure are, at least in part, related to the expansion of the European Union to include many Central and Eastern European countries in 2004.

\subsection{Wage movements across occupations}

This section documents the changes in pay across occupations in recent years. Pay is defined here as the hourly wage rate of full-time workers as captured by a survey of employers (see the 
data appendix for more details). Chart 7 shows how the average occupational wages in selected occupations have evolved relative to the average wage across all occupations. Some occupations have rising relative wages, whereas others have seen falling relative wages. That relative wages have increased for some groups and decreased for others is a well-documented fact in the literature on U.K. wage inequality (see, for example, Machin (2003)). Chart 7a shows that the relative wages of health professionals and corporate managers have risen over time. In contrast, the relative wages of those in sales and customer services have fallen a little in recent years $(C h a r t ~ 7 b)$. Elementary trades and elementary service workers, on the other hand, have experienced little change in their relative wage rates since 1992. So there has been some heterogeneity in changes in relative wages across occupations.

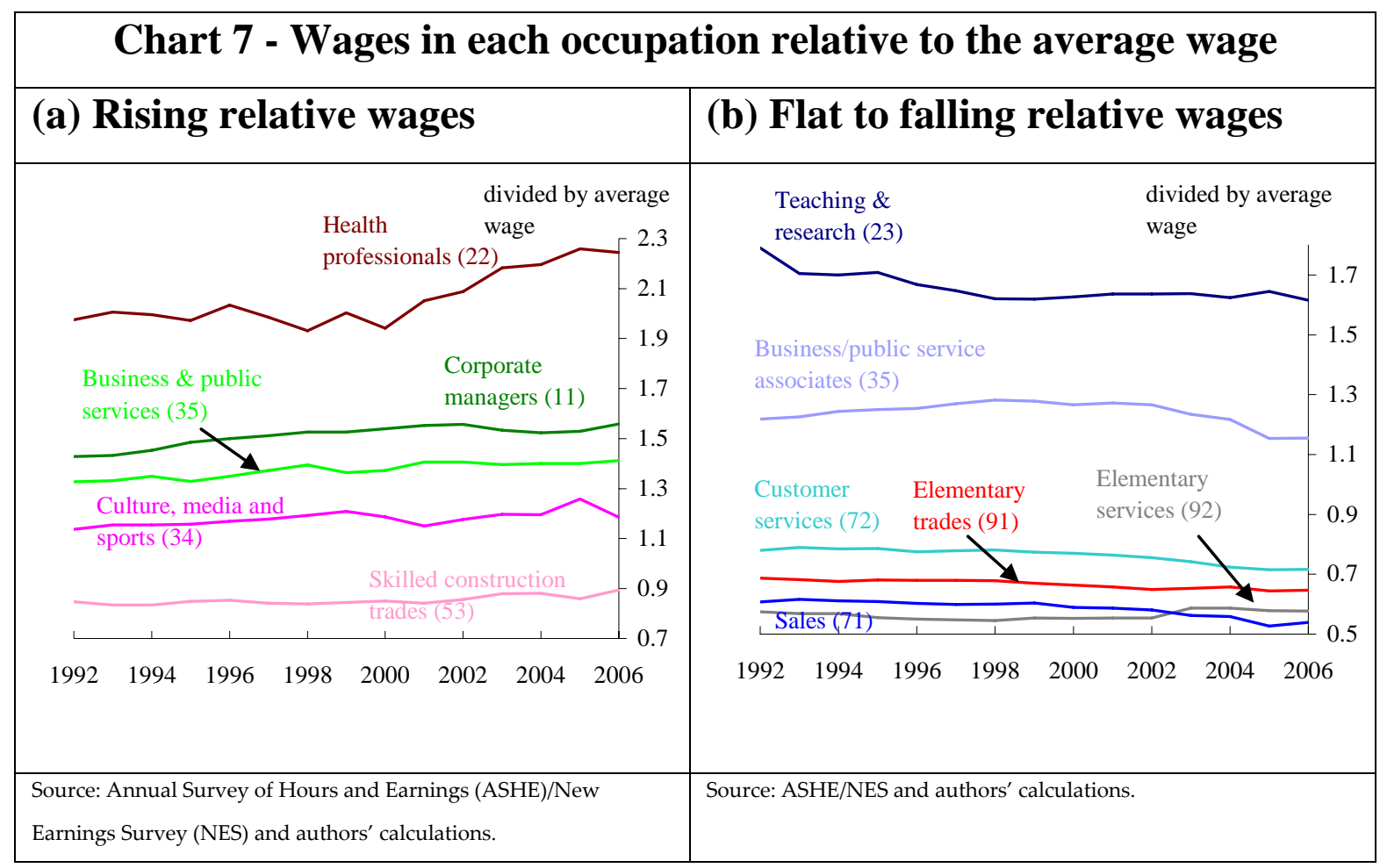

To summarize, this section has documented some facts about how wages and immigration vary across different occupations. It finds that immigrants are most predominant in both high-skill and low-skill occupations and least predominant in middle-skill jobs, but the differences are not 
large. And while the immigrant-native share has continued to increase in all occupations since the mid 1990s, in recent years the rise has been greatest in low-skill occupations. Low-skill occupations, of course, pay wages that are below the average wage rate. But there has been some heterogeneity in the evolution of relative wage rates across occupations over time.

\section{Theoretical background}

Since we are going to undertake an empirical analysis of occupational wage changes, it is helpful to develop a theoretical framework to enable us to interpret the results.

Suppose each region has an aggregate production function of the form

$$
Y_{r t}=F\left(N_{1 r t}, \ldots, N_{I r t}, s_{1 r t}, \ldots, s_{I r t}, K_{r t}, A_{r t}\right),
$$

where $Y$ =output, $N_{i}=$ employment in occupation $i, i=1 \ldots \mathrm{I}, s_{i}=$ share of immigrants in occupation $i, K=$ fixed capital, $A=$ technical change factor, $r=$ region, and $t=$ time. The role of the share of immigrants is to capture the possibility that immigrants are more or less productive than natives or, at least, are thought to be so by the managers of firms who make employment decisions. The demand for regional output is given by

$$
Y_{r t}=\left(P_{r t} / P_{t}\right)^{-\eta_{r t}} D_{r t},
$$

where $P_{r t}=$ the price of regional output, $P_{t}=$ the aggregate price level, and $D_{r t}=$ the regional demand index, which captures the extent to which aggregate demand in a particular region may rise or fall.

If the occupational wages are $W_{i}$, and $K$ and $A$ are predetermined, employment is determined

by solving

$$
\max _{N_{i}, P, Y} P_{r t} Y_{r t}-\sum_{i=1}^{I} W_{i r t} N_{i r t},
$$


subject to (1) and (2). Note that, within occupations, we assume that firms are unable to pay different wages to natives and immigrants, an assumption consistent with current U.K. antidiscrimination legislation. ${ }^{3}$

The first-order conditions are given by

$$
\left(1-\frac{1}{\eta_{r t}}\right) p_{r t} F_{i}\left(N_{1 r t}, \ldots, N_{I r t}, S_{1 r t}, \ldots, S_{I r t}, K_{r t}, A_{r t}\right)=w_{i r t},
$$

where $\mathrm{i}=1, . . \mathrm{I}$, and $p_{r t}=P_{r t} / P_{t}, w_{r t}=W_{i r t} / P_{t}$ are real prices and real wages, respectively. If we make a log-linear approximation of the I equations in (3) and solve for $n_{i r t}=\ln N_{\text {irt }}$, all $i$, we have $n_{i r t}=\alpha_{0}-\alpha_{1} \ln w_{i r t}+\sum_{\substack{j=1 \\ j \neq i}}^{I} \alpha_{1 j} \ln w_{j r t}-\alpha_{2} s_{i r t}+\sum_{\substack{j=1 \\ j \neq i}}^{I} \alpha_{2 j} s_{j r t}+\alpha_{3} \ln \left(p_{r t}\left(1-\frac{1}{\eta_{r t}}\right)\right)+\alpha_{4} \ln K_{r t}+\alpha_{5} \ln A_{r t}+v_{i r t}$

where $i=1, \ldots$ I. Note that we have written these I equations with identical coefficients, with any differences absorbed into the error. This "assumption" is ultimately dropped in our empirical analysis when we estimate models that differ across occupations.

Suppose the cross effects are not large and may be approximated by

$$
\sum_{\substack{j=1 \\ j \neq i}}^{I}\left(\alpha_{1 j} \ln w_{j r t}+\alpha_{2 j} \ln s_{j r t}\right)=\alpha_{i r}^{\prime}+\alpha_{r t}^{\prime}+\alpha_{i t}^{\prime}+v_{i r t}^{\prime}
$$

So we end with a simple regional-occupation labour-demand equation of the form

$$
n_{i r t}=\alpha_{i r}+\alpha_{r t}+\alpha_{i t}-\alpha_{1} \ln w_{i r t}-\alpha_{2} s_{i r t}+v_{i r t}^{1},
$$

\footnotetext{
${ }^{3}$ Of course, in practice, we would have to split employees into age/education groups within occupations to make this assumption totally realistic. These factors are controlled for in the empirical analysis.
} 
where $\alpha_{3} \ln \left(p_{r t}\left(1-\frac{1}{\eta_{r t}}\right)\right)+\alpha_{4} \ln K_{r t}+\alpha_{5} \ln A_{r t}$ are absorbed into $\alpha_{r t}$. Then the cross effects, output prices, capital, and technical change are all captured by the occupation/region effects, $\alpha_{i r}$; the region/time effects, $\alpha_{r t}$; and the occupation/time effects, $\alpha_{i t}$. The impact of the immigrant share is negative $\left(\alpha_{2}>0\right)$ if immigrants are less productive than natives, and positive $\left(\alpha_{2}<0\right)$ if they are more productive. The demand for labour is downward sloping: higher wages discourage labour demand and lower wages encourage it $\left(\alpha_{1}>0\right)$.

Turning to region/occupation labour supply, we suppose an equation of the form

$$
n_{i r t}=\gamma_{i r}+\gamma_{r t}+\gamma_{i t}+\gamma_{1} \ln w_{i r t}-\gamma_{2} u_{i r t-1}+\gamma_{3} s_{i r t-1}+\gamma_{4} X_{i r t}+v_{i r t}^{2},
$$

where $u$ is the unemployment rate and $X$ are other exogenous variables. The idea here is that labour is attracted into region $r$ if wages are higher $\left(\gamma_{1}>0\right)$, if unemployment is lower $\left(\gamma_{2}>0\right)$, and if high immigrant proportions tend to attract mobile workers $\left(\gamma_{3}>0\right)$. If immigrants have a lower reservation wage than natives, then labour supply will be higher for given wages, when the share of immigrants is higher. This is another reason why $\gamma_{3}$ may be positive. It is, of course, possible that high immigrant proportions are a disincentive to move to work in region $r$ and that immigrants have higher reservation wages than natives $\left(\gamma_{3}<0\right)$. Similarly, the immigrant proportion in region $r$ depends on the attractiveness of the region; thus,

$$
s_{i r t}=\beta_{i r}+\beta_{r t}+\beta_{i t}+\beta_{1} \ln w_{i r t}-\beta_{2} u_{i r t-1}+\beta_{3} s_{i r t-1}+\beta_{4} X_{i r t}+v_{i r t}^{3} .
$$

The structure is similar to the labour supply equation, equation (6) (with $\beta_{1}>0$ and $\beta_{2}>0$ ). And $\beta_{3}>0$ is almost certainly positive because it is known that immigrants have a tendency to cluster.

Our analysis concentrates on wage movements, so we consider the wage equation obtained by using (6) and (7) to eliminate $n_{\text {irt }}, s_{\text {irt }}$ from (5). This yields an equation of the following form:

$$
\ln w_{i r t}=\omega_{i r}+\omega_{r t}+\omega_{i t}+\omega_{2} u_{i r t-1}-\omega_{3} S_{i r t-1}+\omega_{4} X_{i r t}+\omega_{i r t}
$$


In particular, the coefficients on $u$ and $s$ are $\left(\gamma_{2}+\alpha_{2} \beta_{2}\right) /\left(\gamma_{1}+\alpha_{1}+\alpha_{2} \beta_{1}\right)$ and $-\left(\gamma_{3}+\alpha_{2} \beta_{3}\right) /\left(\gamma_{1}+\alpha_{1}+\alpha_{2} \beta_{1}\right)$, respectively. Overall, occupation/region wages are driven by basic factors such as regional productivity, regional labour market slack, regional product demand, national occupation demand, and unchanging occupation/region characteristics. All these are captured by the three types of interaction dummies, $\omega_{i r}, \omega_{r t}$, and $\omega_{i t}$. The impact of the lagged immigrant share on pay is negative if $\left(\gamma_{3}+\alpha_{2} \beta_{3}\right)>0$. The denominator $\left(\gamma_{1}+\alpha_{1}+\alpha_{2} \beta_{1}\right)-$ must be positive, because otherwise the model would be unstable. $\gamma_{3}$ is positive if occupation/region labour supply is enhanced by the presence of existing immigrants or if immigrants have a lower reservation wage than natives and, since $\beta_{3}$ is almost certainly positive as we have already noted, $\alpha_{2} \beta_{3}$ is positive if immigrants are, or are thought to be, less productive than natives in the same occupation. So these are the conditions that will tend to generate a negative impact of the pre-existing immigrant share on wages. Finally, note that we are taking account of the feedback effect of wages on the immigrant share by substituting out the current immigrant share using equation (7).

Turning to the unemployment effect, this will be positive if $\left(\gamma_{2}+\alpha_{2} \beta_{2}\right)>0 . \quad \gamma_{2}$ and $\beta_{2}$ are almost certainly positive, because this depends on the uncontroversial notion that high unemployment makes regions less attractive to potential employees. $\alpha_{2}$ is positive if migrants are less productive than natives, as noted above. Overall, we would expect this unemployment effect to be positive. It is worth commenting on how this relates to the standard negative "wage curve" effect of unemployment on wages. This has been absorbed into the region/time dummy, which already captures local labour market slack. What remains is the second-round effect, whereby local occupation-specific unemployment makes the region less attractive, reducing local occupational labour supply and raising pay.

So equation (8) is the basis for our empirical investigation. The analysis in this section has been fundamentally static. In practice, because of adjustment costs of various kinds we would not expect instantaneous adjustment, so we also consider dynamic versions of (8). Finally, equation 
(8) has the same coefficients for all occupations, any differences being absorbed into the error.

To pursue this further, we also investigate models of the same form as (8), except we estimate them separately for different groups of occupations.

\section{Data and results}

The purpose of this section is to investigate whether the lagged immigrant-native ratio in a particular region and occupation has any impact on the average pay rate of that region and occupation. We do this by estimating various forms of equation (8), which we derived in the section above. The primary sources of data for our analysis are the British Labour Force Survey (LFS) and the Annual Survey of Hours and Earnings (ASHE)/New Earnings Survey (NES). ${ }^{4}$ To estimate these equations we use data for 11 U.K. Government Office Regions and 25 2-digit SOC 2000 occupations over 15 years (1992-2006), giving a panel dataset with each observation referring to three dimensions: region, occupation, and time. Based on this level of disaggregation, our dataset has a potential maximum of $4125(=15 \times 11 \times 25)$ observations. ${ }^{5}$

In Section 2, we mentioned that the change in the classification of occupation at the turn of the century introduces a discontinuity in the definitions of occupation within the duration of our dataset. We are able to deal with this discontinuity by transforming or converting the old SOC 1990 classification into the new SOC 2000 classification-that is by creating a consistent definition of occupations throughout our dataset.

For each observation relating to a particular region, occupation, and year cell there is information about the hourly pay rate, the unemployment rate, the immigrant-native ratio, and age and education controls. The age controls include the average age of natives and the average age of immigrants in each region, occupation, and year cell. And the skill level of the native population in each cell is measured by the share of the native population who have a degree, the share of the native population who are students, and the shares of the native population

\footnotetext{
${ }^{4}$ For more details see the data appendix.

${ }^{5}$ If there is no observation relating to a particular region, occupation, and year cell, that cell will be empty and the sample size will be smaller than this maximum.
} 
who have incomplete and complete secondary school qualifications. These qualifications are derived according to the length of time individuals have spent in full-time education. People still in full-time education are classified as students, those who left full-time education before 16 are classified as having incomplete schooling, and those who left after age 21 as having a degree. Individuals who left full-time education between the ages of 16 and 20 are classified as having completed secondary school. 6

Table 1 shows the mean and standard deviations for these key variables over all time periods, regions, and occupations. Over our entire dataset the average hourly wage is $£ 9.48$, the average unemployment rate is 5.2 percent, and the average immigrant-native ratio is 10.2 percent. Most of these immigrants arrived more than two years ago - the ratio of old immigrants to natives is 9.2 percent; the ratio of new immigrants to natives is just below 1 percent. The average age of both immigrants and natives is around 39 years of age, although there is a great deal more variation in the age of immigrants. Seventeen percent of the native population have a degree, with 60 percent having completed school, 2.5 percent still in education, and 21.6 percent having incomplete schooling. The standard deviations capture the extent to which each variable varies across the region, occupation, and year dataset.

\subsection{Pooled specification}

We begin with the pooled estimation of equation (8), where we implicitly assume that the impact of immigration on wages is identical across all occupations. Later, we relax this assumption and allow the impact of immigration on wages to differ by occupation.

In equation (8), the dependent variable refers to log real wages. In practice, we use log nominal wages with the price normalization being absorbed into the region/time dummies. So, does the lagged immigrant-native ratio have any impact on wages? In Table 2, we present the basic static model results, and these show that the immigrant proportion has a significant negative impact on pay. The scale of this impact suggests that if the proportion of immigrants working

\footnotetext{
${ }^{6}$ For more information on this measure of skill see Saleheen and Shadforth (2006) or Manacorda, Manning, and Wadsworth (2006).
} 
in a particular occupation rises by 5 percentage points, the occupational wage falls by around 0.2 percent. This is a relatively small effect. Finally, we may note the positive impact of the unemployment rate, as expected (see Section 3).

Turning to estimates of dynamic versions of equation 8, these are presented in column 2 of Table 2. With 15 time periods, the standard bias on the lagged dependent variable coefficients when estimating fixed effects models is small, so we ignore this problem (see Nickell 1981). The overall picture from the dynamic specification is similar to that of the static specification. The impact of immigration on wages exhibits some persistence, but the long-run coefficient is -0.033 (that is, $(-0.037+0.019) /(1-0.45))$, which is similar to the corresponding coefficient in column 1 ($0.039)$.

Testing for serial correlation in the residuals of the equation in column 1 (Table 3) ${ }^{7}$ gives mixed results, depending on the test that is used. The Baltagi and Li (1995) LM test for first-order serial correlation gives a test statistic with a p-value of 6 percent-suggesting that one can accept the null hypothesis of no serial correlation. ${ }^{8}$ Given the closeness of this p-value to the critical value of 5 percent, we also try a second and stronger Wald test, which is based on Wooldridge (2002). ${ }^{9}$ This indicates a strong rejection of the null. Given these mixed results, we proceed to test the robustness of our results by estimating the same equation but using a different methodology-generalised least squares-allowing for region, occupation-specific first-order serial correlation in the errors. The GLS results are presented in the column (2) of Table 3. The results show that taking first-order serial correlation into account makes very little difference to the result that immigration has a small negative impact on pay.

Given the ongoing controversy in the literature of the impact of immigration on wages, it is important to ask, how reliable are these findings? The reliability of these results depends on the

\footnotetext{
7 This is the same equation as the second column in Table 2.

${ }^{8}$ The LM test statistic takes on the value of 3.44 compared to the 5 percent critical value of 3.84 .

${ }_{9}^{9}$ See page 283 .
} 
accuracy of the data ${ }^{10}$ and the appropriateness of the method of estimation. A common problem faced by most empirical studies that try to estimate the impact of immigration on wages is that the increase in immigration to any particular region or occupation is not clearly exogenous. In particular, if immigrants are likely to be attracted to areas with strong demand, then any empirical relationship relating the immigrant-native ratio to wages will tend to pick up a spurious positive correlation that will result in the an upwardly biased coefficient of the immigration-native ratio. Our model takes account of these channels and delivers an equation in which wages are related to the lagged immigrant-native ratio. But even the lagged immigrant ratio may not be clearly exogenous. Shocks that hit a region and occupation may be correlated over time. This leads to serially correlated errors in the presence of which the lagged immigrant-native ratio will be correlated with the error term. In that case the coefficient on the lagged immigrant-native ratio may continue to be biased upwards. That is, the true impact of immigration on wages is likely to be larger than the values reported in Tables $2-3$. It would be good to have some idea about the size of the bias. The bias will be bigger, the bigger is the autocorrelation coefficient $(\rho)$; but the average value of this coefficient over occupations and regions is -0.04 , suggesting that the bias from this source is likely to be negligible.

How should one interpret these findings? The model outlined above suggests certain conditions that must hold in order for the impact of the immigrant-native ratio on wages to be negative. These include: (i) that firms believe (rightly or wrongly) that immigrants are less productive than natives and (ii) that immigrants have lower reservation wages than natives or that occupation/region labour supply is likely to be enhanced by the presence of existing immigrants. Our findings cannot tell us anything about any of the above conditions in isolation, rather they suggest that either both conditions are true or that only one is true but its impact is large enough to dominate.

\footnotetext{
${ }^{10}$ For a discussion of the accuracy of immigration data see the box on page 376-377 of Saleheen and Shadforth (2007).
} 


\subsection{Occupational-level specification}

So while immigration appears to have a negative impact on occupational pay, the overall average effect is relatively small. It is natural to ask whether we can find bigger effects in particular occupations. To do this, we divide the 25 2-digit occupations into five groups: managers, professionals, skilled production workers, semi/unskilled production workers, and semi/unskilled services workers. ${ }^{11}$

There is no particular reason to expect the parameters in the theoretical model to be the same across occupations. Rather, one might expect there to be heterogeneity across occupations. This heterogeneity probably reflects a variety of factors. It may be the case that immigrants are perceived as being more productive than natives in some occupations but not in others. It may be that different occupations have been hit by different shocks or that different occupations have been hit by the same shocks but to differing degrees. For example, it may be the case that immigrants entering skilled jobs have done so primarily as a result of a positive demand shock. Faced with shortages of these skilled workers, firms may need to be more active in recruitment and offer competitive wages to attract foreign workers. At the other end of the spectrum, it may also be the case that immigrants entering semi/unskilled service jobs have done so primarily as a result of supply shocks (such as the EU Accession). In this case, their reservation wages may be lower than those of natives, reflecting the lower wage rates they might earn in their home countries. These examples highlight how potential differences in immigrant and firm behaviour across occupations can show up as differences in the impact of immigration on wages across occupations.

Estimates across these five broad occupation groups are reported in Table $4 . .^{12}$ For each occupation, the static equation results are reported in the first row and the dynamic equation results in the second row. Not surprisingly, the results show that there are clear differences

\footnotetext{
${ }^{11}$ Details may be found in the data appendix.

${ }^{12}$ Estimates based on each of the detailed 25 occupations can also be seen in Table A2 (for the static model) and Table A3 (for the dynamic model). Note that the average of the coefficients reported in Table A2 - that is the average across the 25 occupational equations - is - 0.046 , very close to the result obtained from estimating the pooled model that is reported in Table 2.
} 
across occupations. The static results suggest that the negative effects of immigration on wages are concentrated among managers, skilled production workers, semi/unskilled production workers and semi/unskilled service workers: that is all the occupational groups except professionals. However, the fact that the lagged dependent variable coefficient in the first group exceeds unity suggests that the effect on managers is spurious. This leaves the skilled production sector, the semi/unskilled production sector and semi/unskilled service sector as those areas of the economy where immigration has a serious negative impact on pay. In the latter case, the coefficient indicates that a 10 percentage point rise in the proportion of immigrants working in semi/unskilled services - that is, in care homes, bars, shops, restaurants, cleaning, for example-lead to a 5.2 percent reduction in pay. The dynamic model suggests the long-run reduction in pay is of similar size (5.8 percent $\left.=0.070 /(1-.75)^{*} 10\right)$. The dynamic models in general show that there is less wage inertia (a smaller coefficient on the lagged dependent variable) and so faster adjustment back to equilibrium in the low skill occupations.

What should we make of the finding that immigration has a bigger impact on wages in low skill occupations? Our earlier investigation into the facts about immigration unveiled that low-skill occupations, such as semi-unskilled services, had witnessed the largest increases in immigration in recent years. Now we have found that the impact of immigration on wages is largest in these sectors. Taken together, these could imply a combination of two things. First compositional effects: wages are falling in low skill occupations because there are more immigrants who simply earn less. Second, average wages in these sectors may have fallen by more than in high skill sectors, in part because they have been hit by a larger shock (the rise in immigration).

To get a sense of which of the two effects might dominate, we ask how large is the compositional affect? The compositional affect will be determined by the wage differential between immigrants and natives within occupations and the extent of the rise in immigration. ${ }^{13}$

\footnotetext{
${ }^{13}$ The wage data that we have used thus far (from the NES) are not broken down into immigrant and native sub-groups. But the LFS survey that we have used for data on immigration does have individual information on wages and so can by split by natives and immigrants. The LFS wage data comes from a smaller sample and so is of a lower quality than NES wage data, nevertheless it is useful in indicating whether immigrants earn more or less than natives.
} 
A simple hourly wage equation suggests that, in semi/unskilled services, immigrants typically earn 6 percent less than natives (Table 5). ${ }^{14}$ In other words a 10\% rise in immigration alone, would lead to a 0.6 percent fall in wages - that is the size of the compositional affect. Clearly there are large uncertainties about the exact size of the compositional effect. What is striking, however, is that the compositional effect is tiny when compared to the total impact of 5.2 percent on pay in the semi/unskilled services sector as reported above. From this we conclude that the impact of immigration on wages in semi/unskilled services is much larger than can be accounted for by purely compositional effects, suggesting that the vast majority of this effect refers to the impact on native workers. That is average wages in the low skilled sectors, which have also seen the biggest rise in immigration are likely to have fallen mainly because of the fall in native pay.

\section{Conclusions}

This paper asks whether immigration has any impact on wages. It answers this question by considering the variation of wages and immigration across regions, occupations, and time. Occupations turn out to be a relatively important dimension. Once the occupational breakdown is incorporated into a regional analysis of immigration, the immigrant-native ratio has a small negative impact on the average occupational wage rates of that region. Closer examination reveals that the biggest effect is in the semi/unskilled services sector, where a 10 percentage point rise in the proportion of immigrants is associated with a 5 percent reduction in pay. This finding accords well with intuition and anecdotal evidence, but does not seem to have been recorded previously in the empirical literature.

\footnotetext{
${ }^{14}$ Across all occupations immigrants earn 7 percent less than natives (Table 5).
} 


\section{Table 1}

Means of Variables

\begin{tabular}{|c|c|c|}
\hline & Mean & $\begin{array}{l}\text { Standard } \\
\text { deviation }\end{array}$ \\
\hline \multicolumn{3}{|l|}{ Dependent variable } \\
\hline $\mathrm{w}_{\text {irt }}\left(£^{\prime} \mathrm{s}\right)$ & 9.48 & 4.08 \\
\hline $\ln \mathrm{w}_{\mathrm{irt}}$ & 2.17 & 0.39 \\
\hline \multicolumn{3}{|l|}{ Independent variables } \\
\hline immigrant/native ratio $_{\text {irt }}$ & 0.102 & 0.140 \\
\hline new immigrant/native ratio ${ }_{\text {irt }}$ & 0.009 & 0.023 \\
\hline old immigrant/native ratio $_{\text {irt }}$ & 0.092 & 0.130 \\
\hline unemployment rate $_{\text {irt }}$ & 0.052 & 0.039 \\
\hline \multicolumn{3}{|l|}{ age controls } \\
\hline mean immigrant age $_{\text {irt }}$ (years) & 38.67 & 4.29 \\
\hline mean native age irt (years) & 39.00 & 2.74 \\
\hline \multicolumn{3}{|l|}{ skill controls } \\
\hline share of native population & & \\
\hline - with degree & 0.166 & 0.204 \\
\hline - with completed school & 0.600 & 0.144 \\
\hline - still in education & 0.025 & 0.039 \\
\hline - with incomplete schooling & 0.216 & 0.122 \\
\hline
\end{tabular}

Source: Labour Force Survey and Annual Survey of Hours and Earnings/New Earnings Survey. 


\section{Table 2}

\section{The Impact of Immigration on Wages (Eq. 8)}

\begin{tabular}{|c|c|c|}
\hline Dependent variable, In wirt & static model & dynamic model \\
\hline $\ln \mathrm{w}_{\text {irt-1 }}$ & - & $\begin{array}{r}0.45 \\
{[25.35]}\end{array}$ \\
\hline (immigrant/native ratio) $_{\text {irt-1 }}$ & $\begin{array}{r}-0.039 \\
{[-2.04]}\end{array}$ & $\begin{array}{c}-0.037 \\
{[-1.84]}\end{array}$ \\
\hline (immigrant/native ratio) $_{\text {irt-2 }}$ & - & $\begin{array}{r}0.019 \\
{[0.85]}\end{array}$ \\
\hline (unemployment rate) irt-1 & $\begin{array}{r}0.096 \\
{[2.42]}\end{array}$ & $\begin{array}{r}0.071 \\
{[1.76]}\end{array}$ \\
\hline (unemployment rate) ${ }_{\text {irt-2 }}$ & - & $\begin{array}{r}-0.003 \\
{[-0.08]}\end{array}$ \\
\hline Sample size & 3771 & 3468 \\
\hline $\bar{R}^{2}$ & 0.99 & 0.99 \\
\hline
\end{tabular}

Notes:

(i) The equation is estimated using ordinary least squares (OLS).

(ii) Asymptotic t-ratios in parenthesis.

(iii) $\mathrm{t}=$ time (15 years, 1992-2006), $\mathrm{i}=$ occupation (25 2-digit occupations), $\mathrm{r}=$ region (11 Government Office Regions). Observations are missing because some of the cells have missing information.

(iv) The equation also contains age controls (mean immigrant age, mean native age), skill controls (share of native population with degree, with completed school, still in education), region/year dummies, occupation/year dummies, and region/occupation dummies. 
(v) With fifteen time periods, the standard bias on the lagged dependent variable coefficients when estimating fixed effects models is small, so we ignore this problem (see Nickell 1981).

Source: Labour Force Survey and Annual Survey of Hours and Earnings/New Earnings Survey. 
Table 3

The Impact of Immigration on Wages, Dynamic Model (Eq. 8)

Testing for serial correlation

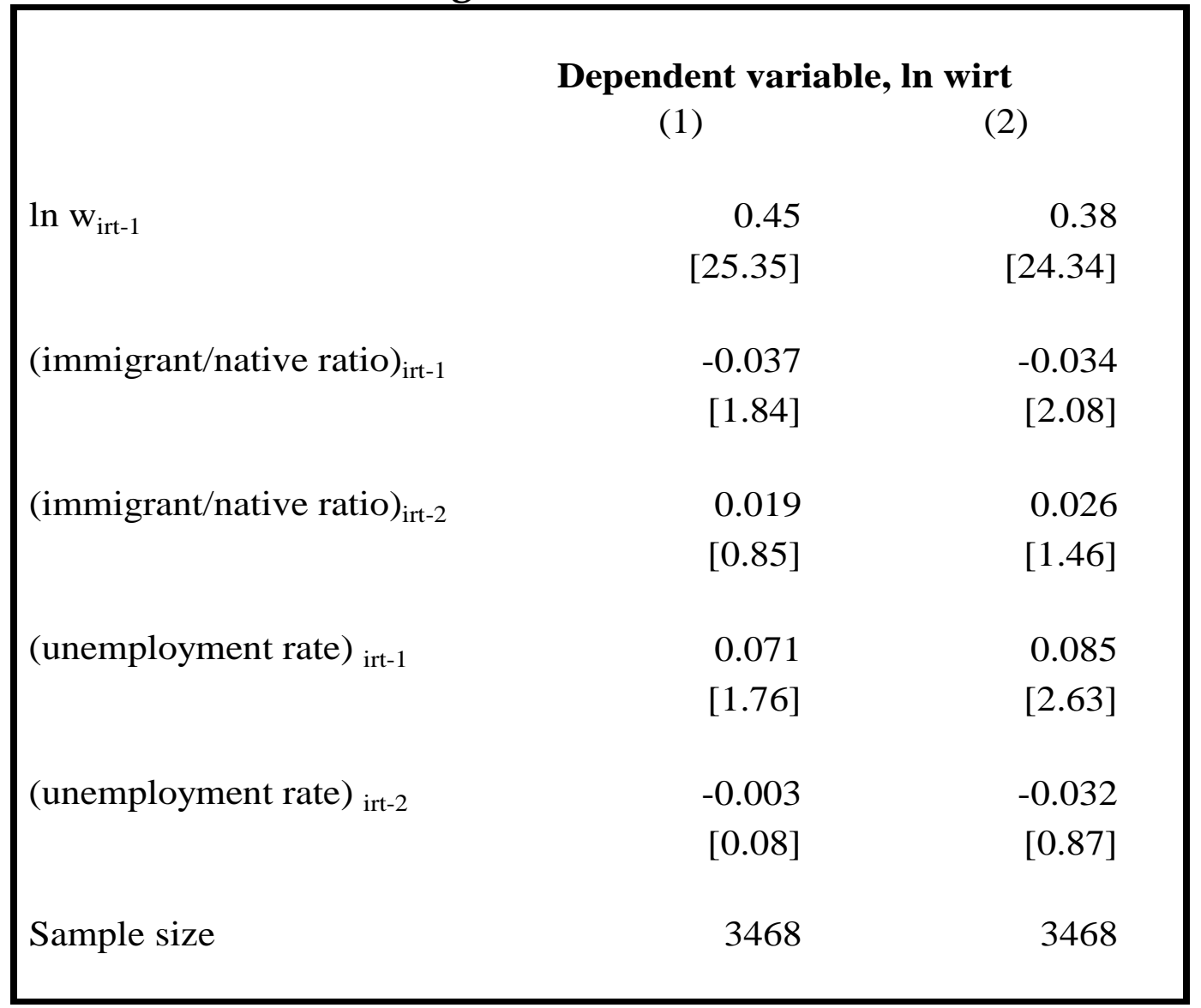

Notes:

(i) The equation in column (1) is estimated using OLS. The equation in column (2) is estimated using GLS, allowing for occupation and region-specific first-order serial correlation.

(ii) Notes (ii), (iii), (iv), Table 2; Note (ii), Table 3.

(iii) Serial Correlation: For the equation in column (1), assuming a structure of the form, $\omega_{i r t}=\rho \omega_{i r t-1}+u_{i r t}$, the null of $\rho=0$ is accepted using the Baltagi and Li (1995) LM test, but the null is rejected using the stronger Wooldridge (2002) Wald test.

Source: Labour Force Survey and Annual Survey of Hours and Earnings/New Earnings Survey. 
Table 4

Impact of Immigration on Wages: Occupational Groups

\begin{tabular}{|c|c|c|c|c|c|c|}
\hline & \multicolumn{6}{|c|}{ Dependent variable, In wirt } \\
\hline & $\ln \mathrm{w}_{\text {irt-1 }}$ & t-ratio & $\begin{array}{l}\text { immigrant/natıve } \\
\text { ratio }\end{array}$ & $\begin{array}{l}\text { absolute } \\
\text { t-ratios }\end{array}$ & Sample size & $\bar{R}^{2}$ \\
\hline \multirow[t]{2}{*}{ Managers } & - & & -0.391 & {$[2.43]$} & 308 & 0.88 \\
\hline & 1.02 & [46.05] & 0.036 & {$[0.65]$} & 308 & 0.99 \\
\hline \multirow[t]{2}{*}{ Professionals } & - & & 0.037 & {$[0.96]$} & 1336 & 0.83 \\
\hline & 0.95 & [87.28] & 0.033 & [2.31] & 1330 & 0.98 \\
\hline \multirow[t]{2}{*}{ Skilled Production } & - & & -0.233 & [5.29] & 742 & 0.76 \\
\hline & 0.91 & {$[58.08]$} & -0.049 & {$[2.65]$} & 738 & 0.96 \\
\hline \multirow[t]{2}{*}{ Semi/unskilled production } & - & & -0.251 & {$[4.95]$} & 302 & 0.97 \\
\hline & 0.75 & [16.69] & -0.086 & {$[2.34]$} & 302 & 0.99 \\
\hline \multirow[t]{2}{*}{ Semi/unskilled services } & - & & -0.522 & [10.32] & 769 & 0.90 \\
\hline & 0.88 & {$[50.47]$} & -0.070 & {$[2.72]$} & 769 & 0.98 \\
\hline
\end{tabular}

Notes:

(i) Each equation also includes lagged unemployment, age controls, skill controls, year dummies, and region dummies.

(ii) Notes (i), (iii), (iv), Table 2; Note (ii), Table 3.

Source: Labour Force Survey and Annual Survey of Hours and Earnings/New Earnings Survey. 


\section{Table 5 \\ Wage Equations: All Occupations and by Occupational Groups}

\begin{tabular}{|llllll|}
\hline \multicolumn{5}{|c|}{ Dependent variable, ln (hourly wage $_{\mathbf{k t}}$ ) } \\
& & & & \\
& Immigrant $_{\mathrm{kt}}$ & $\mathrm{t}$-ratio & Sample size & $\bar{R}^{2}$ \\
& & & & \\
All occupations & -0.07 & {$[24.33]$} & 325994 & 0.49 \\
& & & & \\
\hline Managers & -0.08 & {$[8.82]$} & 45653 & 0.21 \\
Professionals & -0.04 & {$[7.91]$} & 86692 & 0.22 \\
Skilled Production & -0.15 & {$[13.69]$} & 27399 & 0.21 \\
Semi/unskilled production & -0.10 & {$[13.46]$} & 36183 & 0.12 \\
Semi/unskilled services & -0.06 & {$[11.49]$} & 82615 & 0.13 \\
\hline
\end{tabular}

Notes:

(i) Each equation is estimated using ordinary least squares.

(ii) Each equation also contains age, age squared, skill controls (share of native population with degree, with completed school, still in education), region dummies, and year dummies. The first equation (row 1) also includes occupation dummies.

(iii) $\mathrm{t}=$ time (6 years, 2001-2006), $\mathrm{k}=$ individuals.

Source: Labour Force Survey. 


\section{References}

Baglati, Badi and Qi Li (1995), “Testing AR(1) against MA(1) disturbances in an error component model," Journal of Econometrics 68: 133-151.

Beaudry, Paul, Mark Doms, and Ethan Lewis (2006), "Endogenous skill bias in technology adoption: city level evidence from the IT revolution," Federal Reserve Bank of San Francisco Working Paper no. 06-24.

Borjas, George (2003), "The labour demand curve is downward sloping," Quarterly Journal of Economics 116(4): 463-486.

Borjas, George (2005), Labour Economics, Third Edition, McGraw-Hill Irwin publishers.

Card, David (1990), “The impact of the Mariel Boatlift on the Miami labour market,",Industrial and Labour Relations Review 43(2): 245-257.

Card, David and John diNardo (2000), “Do immigrant inflows lead to native outflows?" American Economic Review, Papers and Proceedings 90(2): 360-367.

Card, David (2005), “Is the new immigration really so bad?” Economic Journal 115(507): 300-323.

Dustmann, Christian, Francesca Fabbri, and Ian Preston (2005), “The impact of immigration on the British Labour Market," Economic Journal 115(507): 324-341.

Hatton, Timothy (2002), "Why has UK net immigration increased?" Australian National University, Centre for Economic Policy Research Discussion Paper no. 457.

King, Mervyn (2007), 'The Governor's speech to CBI Wales/CBI Cymru, Cardiff', Bank of England Quarterly Bulletin, 2007Q3: 422-424.

Layard, Richard, Stephen Nickell, and Richard Jackman (1991), Unemployment: macroeconomic performance and the labour market, Oxford University Press.

Lemos, Sara, Jonathan Portes (2008), "New labour? The impact of migration from the new European Union Member States ont eh UK labour market," IZA Discussion Paper no. 3756.

Lewis, Ethan (2004), “Local open economies within the U.S.: how do industries respond to immigration?" Federal Reserve Bank of Philadelphia Working Paper no. 04-1.

Lewis, Ethan (2005), "Immigration, skill mix and the choice of technique," Federal Reserve Bank of Philadelphia Working Paper no. 05-8. 
Machin, Stephen (2003), “Wage inequality since 1975," in R. Dickens, P. Gregg, and J Wadsworth (eds.), The Labour Market Under New Labour, Palgrave Macmillan.

Manacorda, Marco, Alan Manning, and Jonathan Wadsworth (2006), "The impact of immigration on the structure of male wages: theory and evidence from Britain," London School of Economics, CEP Discussion Paper no. 754.

Nickell, Stephen (1981), “Biases in dynamic models with fixed effects," Econometrica 49(6): 1417-26.

Ottaviano, Gianmarco and Giovanni Peri (2006), "Rethinking the gains from immigration: theory and evidence from the U.S.," NBER Working Paper no. 11672.

Ottaviano, Gianmarco and Giovanni Peri (2008), "Immigration and National Wages: Clarifying the Theory and the Empirics," NBER Working Paper no. 14188.

Pesaran, Hashem and Ron Smith (1995), "Estimating long-run relationships from dynamic heterogeneous panels," Journal of Econometrics 68: 79-113.

Reed, Howard and Maria Latorre (2009), "The Economic Impacts of Migration on the UK Labour Market", Institute of Public Policy Research.

Saleheen, Jumana and Chris Shadforth (2006), "The economic characteristics of immigrants and their impact on supply," Bank of England Quarterly Bulletin, 2006Q4: 374-385.

Wooldridge, Jeffrey (2002), Econometric analysis of cross section and panel data, MIT Press. 


\section{Data Appendix}

The data used for our analysis come from the British Labour Force Survey (LFS) and the Annual Survey of Hours and Earnings (ASHE)/New Earnings Survey (NES). The LFS is a quarterly sample survey of households living at private addresses in Great Britain and is carried out by the Office of National Statistics. The ASHE/NES is an annual sample survey of the earnings of employees in Great Britain based on a 1 percent sample of employees who are members of PayAs-You-Earn (PAYE) income tax schemes. It does not cover the self-employed. It is a survey of employers and is considered to be the most comprehensive source of information on wages.

We use data from these two sources to form a panel dataset that has three dimensions: time, region, and occupation. In other words, for each year of the 15 years (1992-2006) of data that we consider, there are observations for each of the 11 U.K. standard Government Office Regions, and within each region there is information on each of the 25 occupations defined at the 2-digit SOC 2000 classification. In total, in the absence of missing observations, the dataset will have a maximum of $4125(=15 \times 11 \times 25)$ observations. If there is no observation for a given cell, then that data point is missing. A typical static regression has 3771 observations.

\section{Region:}

Standard Government Office Regions (GORs).

\section{Occupation:}

In our panel dataset, occupations are classified according to SOC 2000 throughout.

An important data problem encountered was that the variables required were not available on the SOC 2000 basis through time. This is because there has been a major change in the classification of occupations from SOC 1990 to the SOC 2000 classification in 2001/2002. This paper therefore devises a methodology to transform SOC 1990 into SOC 2000. 
Transforming SOC 1990 to SOC 2000

The Office of National Statistics (ONS) does not provide a match between SOC 1990 and SOC 2000. Indeed, they argue that there is no "formula" that will allow one simply to match the two classifications. In other words, if one were to classify 100 people into the SOC 1990 and SOC 2000 occupations, it is unlikely that all the people from a single category of SOC 1990 would end up in the same single category of SOC 2000. Instead, individuals from one category of SOC 1990 are likely to end up in multiple categories of SOC 2000.

To transform SOC 1990 to SOC 2000, a matrix that allocates the same people to both sets of codes is derived. Such a dual coding of occupations for the same people is obtained from the panel component of neighboring LFS surveys. The LFS 2000:Q4 survey coded occupations based on SOC 1990. and the LFS 2001:Q1 survey coded occupations based on SOC 2000. Taking the individuals who were surveyed in both quarters and who did not change jobs during that time, one is able to obtain 55,000 individuals with dual occupational codes.

This matrix of dual occupation codes allows us to map individuals from SOC 1990 to SOC 2000. The matrix relates to one point in time and so is time invariant. As the mapping is not one-toone (the off diagonal cells are non-zero), a "proportional" mapping method is used. Proportional mapping is a method in which a given proportion of individuals in SOC 1990 are assigned to one category in SOC 2000, with another proportion being assigned to another category in SOC 2000, and so on. The proportions that need to be assigned to each category are determined from the elements of the matrix. For example, assume that there are only two categories of SOC 1990 and SOC 2000. And assume that 70 percent of individuals in category 1 of SOC 1990 fall into category 1 of SOC 2000, and 30 percent fall into category 2. Then, the proportions of SOC 1990 individuals going to categories 1 and 2 will be 0.7 and 0.3 , respectively. In the paper, 3-digit SOC 1990 (371 categories) is mapped into 2-digit SOC 2000 (25 categories), so the matching is likely to more accurate.

The mapping of occupations allows any variable that is defined on the SOC 1990 basis to be transformed into the SOC 2000 basis. This transformation has to be applied to all the variables 
that are used in our dataset. For variables that are derived from the LFS, the occupational codes change in 2001, and for variables that are derived from ASHE/NES, the occupational codes change in 2002.

This transformation is successful for the majority of regions and occupations but less successful for a handful of cells. Success is determined if the transformed variable (that is, the wage rate, employment rate, or immigrant-native ratio) does not jump up or down in the year when the new occupational classification is introduced, that is, in the year of the data break point (2001 for LFS source variables and 2002 for the ASHE/NES source variables). The discontinuity (or jump) is not noticeable for the vast majority of observations, but it is clearly an issue for some. To deal with this jump, whether big or small, the transformed data are spliced onto the data for the later years; crudely speaking, this involves a level shift in the data after the data break point. The splicing takes place by taking the average growth rate of each variable in the three years before the break point and projecting this growth rate forward to link the data on either side of the break point. For consistency purposes, we do this for all cells and all variables excluding the average age of natives and immigrants. The default strategy in the paper is to report all results based on all the spliced variables but non-spliced average age variables.

The reason for not splicing the average age variables is as follows. As will be noted below, the average age refers to the average age of individuals aged between 16 and 65. But as the sample of immigrants is small, on a handful of occasions the act of splicing (and projecting forward past years' growth rates) results in average ages in certain regions and occupations that are greater than 65. Using the spliced average age variables thus seems inappropriate.

In Table 4, results are presented on various groups of occupations. The 2-digit occupations we use are set out in Table A1. The groups used in Table 4 are managers $(11,12)$, professionals $(21$, 22, 23, 24, 31, 32, 35), skilled production workers (51, 52, 53, 54, 81) semiskilled/unskilled production workers $(82,91)$, and semiskilled/unskilled services workers $(61,62,71,72.92)$. 


\section{Wages:}

Hourly wage rates of all full-time workers by region and occupation. Based on adult rates for those whose pay was not affected by absence during the week in which the survey was carried out.

Source: ASHE 2002-2006 published data files from Table 3.6a based on SOC 2000. Prior to 2002, these data are constructed from the NES (1992-2001) micro data files, where occupations are defined at the 3-digit SOC 1990 level.

\section{Employment:}

Individuals aged 16-65 who report being in employment by region and occupation.

Source: LFS 1992-2006 seasonal quarters.

\section{Unemployment:}

The unemployment rate is measured by taking the number of individuals aged 16-65 who are unemployed according to the LFS definition and dividing by the total number of individuals aged 16-65 who are employed and unemployed. The unemployment rate is constructed for each occupation and region cell.

Source: LFS 1992-2006 seasonal quarters.

\section{Immigrant-native ratio}

The number of foreign born individuals (or "immigrants") aged 16-65 divided by the number of individuals aged 16-65 who were born in the United Kingdom ("natives"). This ratio is constructed for each occupation and region cell.

Source: LFS 1992-2006 seasonal quarters.

\section{New immigrant-native ratio:}

"New" immigrants are defined as those immigrants (foreign-born workers) who arrived in the United Kingdom in the year of the survey or the previous calendar year. The "new" immigration-native ratio takes the number of new immigrants aged 16-65 in each occupation and region and divides it by the number of natives aged 16-65 in that same occupation and region.

Source: LFS 1992-2006 seasonal quarters. 


\section{Old immigrant-native ratio:}

"Old" immigrants are defined as those immigrants (foreign-born workers) who are not new immigrants. They are defined as the difference between the total number of immigrants and the number of new immigrants. The "old" immigration-native ratio takes the number of old immigrants aged 16-65 in each occupation and region and divides it by the number of natives aged 16-65 in that same occupation and region.

Source: LFS 1992-2006 seasonal quarters.

\section{Average Age:}

The average age of natives and immigrants aged 16-65 by region and occupation.

Source: LFS 1992-2006 seasonal quarters.

\section{Education:}

The skill level of each region and occupation cell is measured by the level of education held by the native inhabitants aged 16-65 in each region and occupation cell. Four levels of education are defined and used in this paper: those who have a degree; those who have completed school; those who have incomplete or no schooling; and those who are still in full-time education. These educational variables are defined according to the age at which the worker left full-time education. Completing education at the age of 21 is used to proxy completion of a degree. If education was completed before the age of 16, it is taken to proxy incomplete schooling; and if education was completed between the ages of 16 and less than 21, it is taken to imply that schooling has been completed (see Saleheen and Shadforth 2006 for details). The skill control variables take the form of the share of natives who hold a degree, have completed school, have incomplete schooling, or are still in full-time education. As defined, the sum of these four skill shares will sum to 1 .

Source: LFS 1992-2006 seasonal quarters. 
Table A1

Immigrant Proportions in 2-Digit Occupations

\section{SOC2000}

11 Corporate managers

12 Agriculure managers

21 Science professionals

22 Health professionals

23 Teaching \& research

24 Business \& public services

31 Science associates

32 Health associates

33 Protective services

34 Culture, media and sports

35 Business/public service associates

41 Administrative

42 Secretarial

51 Skilled agricultural trades

52 Skilled metal and electrical trades

53 Skilled construction trades

54 Textiles and printing trades

61 Caring and personal services

62 Leisure and personal services

71 Sales

72 Customer services

81 Process operatives

82 Transport operatives

91 Elementary trades

92 Elementary services
$92-94 \quad 98-00 \quad 04-06$

$\begin{array}{lll}0.090 & 0.096 & 0.111 \\ 0.119 & 0.125 & 0.149 \\ 0.089 & 0.111 & 0.146 \\ 0.285 & 0.345 & 0.462 \\ 0.095 & 0.109 & 0.127 \\ 0.105 & 0.111 & 0.135 \\ 0.071 & 0.084 & 0.151 \\ 0.134 & 0.134 & 0.179 \\ 0.061 & 0.048 & 0.051 \\ 0.118 & 0.141 & 0.147 \\ 0.079 & 0.087 & 0.105 \\ 0.071 & 0.081 & 0.094 \\ 0.075 & 0.088 & 0.117 \\ 0.028 & 0.036 & 0.058 \\ 0.056 & 0.054 & 0.064 \\ 0.051 & 0.048 & 0.086 \\ 0.119 & 0.137 & 0.211 \\ 0.080 & 0.085 & 0.124 \\ 0.073 & 0.087 & 0.121 \\ 0.065 & 0.076 & 0.105 \\ 0.067 & 0.078 & 0.091 \\ 0.095 & 0.093 & 0.109 \\ 0.067 & 0.070 & 0.113 \\ 0.067 & 0.071 & 0.107 \\ 0.090 & 0.100 & 0.140\end{array}$


Table A2

\section{Impact of Immigrant on Wages: 25 Occupations}

(Static Model)

\begin{tabular}{|c|c|c|c|c|c|}
\hline \multicolumn{6}{|c|}{$\begin{array}{l}\text { The impact of immigration on wages: across occupation } \\
\text { Dependent variable is In wirt }\end{array}$} \\
\hline & $\begin{array}{l}\text { 2-digit } \\
\text { code }\end{array}$ & $\begin{array}{l}\text { immigrant/native } \\
\text { share }{ }_{\text {irt-1 }}\end{array}$ & t-stat & $\begin{array}{c}\text { sampl } \\
\text { size }\end{array}$ & $\begin{array}{l}\text { e adjusted } \\
\text { R-squarec }\end{array}$ \\
\hline Corporate managers & 11 & 0.003 & {$[0.01]$} & 154 & 0.98 \\
\hline Managers and proprietors in agri and services & 12 & $0.248 *$ & [2.18] & 154 & 0.96 \\
\hline Science and technology profs & 21 & 0.034 & {$[0.55]$} & 153 & 0.98 \\
\hline Health professionals & 22 & -0.067 & {$[0.86]$} & 132 & 0.87 \\
\hline Teaching and research profs & 23 & -0.148 & [1.87] & 154 & 0.98 \\
\hline Business and public service profs & 24 & -0.166 & [1.15] & 151 & 0.97 \\
\hline Science and technology associate profs & 31 & $-0.123^{*}$ & [2.95] & 153 & 0.99 \\
\hline Health and social welfare associate profs & 32 & 0.040 & {$[0.83]$} & 152 & 0.99 \\
\hline Protective service occs & 33 & 0.168 & [1.44] & 148 & 0.95 \\
\hline Culture, media and sports occs & 32 & 0.236 & {$[0.96]$} & 139 & 0.9 \\
\hline Business and public service assoc profs & 35 & $-0.580 *$ & [3.93] & 154 & 0.99 \\
\hline Administrative occupations & 41 & 0.025 & {$[0.35]$} & 154 & 1 \\
\hline Secretarial and related occs & 42 & 0.048 & {$[0.86]$} & 154 & 0.99 \\
\hline Skilled agricultural trades & 51 & 0.074 & {$[0.41]$} & 139 & 0.89 \\
\hline Skilled metal and electrical trades & 52 & $0.171 *$ & [3.51] & 154 & 0.99 \\
\hline Skilled construction and building trades & 53 & 0.074 & [1.17] & 147 & 0.98 \\
\hline Textiles, printing, and other skilled trades & 5 & 0.029 & {$[0.83]$} & 154 & 0.98 \\
\hline Caring personal service occupations & 61 & $-0.352 *$ & [3.11] & 154 & 0.95 \\
\hline Leisure and other personal service occs & 62 & -0.020 & [0.19] & 153 & 0.97 \\
\hline Sales occupations & 71 & $-0.474 *$ & [5.24] & 154 & 0.96 \\
\hline Customer service occupations & 72 & -0.134 & [1.45] & 154 & 0.97 \\
\hline Process, plant and machine operatives & 81 & 0.028 & {$[0.82]$} & 154 & 0.99 \\
\hline Transport and mobile machine drivers and ope & ratives 82 & -0.092 & {$[1.23]$} & 148 & 0.99 \\
\hline Elementary trades, plant, and storage rel occs & 91 & -0.011 & {$[0.18]$} & 154 & 0.99 \\
\hline Elementary admin and service occs & 92 & $-0.158 *$ & [4.13] & 154 & 0.99 \\
\hline
\end{tabular}

Notes:

(i) All equations are estimated using OLS. Each equation also includes lagged unemployment, age controls, skill controls, year dummies and region dummies.

(ii) Notes (ii), (iii) and (v) Table 2. 


\section{Table A3.}

Impact of Immigrant on Wages: 25 Occupations (Dynamic Model)

\section{The impact of immigration on wages: across occupation Dependent variable is In wirt}

Corporate managers

Managers and proprietors in agri and services

Science and technology profs

Health professionals

Teaching and research profs

Business and public service profs

Science and technology associate profs

Health and social welfare associate profs

Protective service occs

Culture, media and sports occs

Business and public service assoc profs

Administrative occupations

Secretarial and related occs

Skilled agricultural trades

Skilled metal and electrical trades

Skilled construction and building trades

Textiles, printing and other skilled trades

Caring personal service occupations

Leisure and other personal service occs

Sales occupations

Customer service occupations

Process, plant and machine operatives

Transport and mobile machine drivers and operat

Elementary trades, plant and storage rel occs
Soc 2000

\section{2 digit} code

immigrant/nativ e share $_{\text {irt-1 }}$ 11

12 0.021

0.140 t-stat

sample adjusted

2

21

22

23

24

31

32

$0.031 \quad[0.58]$

-0.053 [0.75]

-0.102 [1.41]

$-0.095$

$-0.037$

[0.77]

[1.07]

0.012 [0.27]

$0.078 \quad$ [0.73]

0.233

[0.98]

$-0.348 *[2.85]$

$0.011 \quad[0.16]$

0.038

[0.70]

$-0.385$

[1.53]

0.049 [0.73]

0.012 [0.38]

$-0.302 *[2.55]$

-0.079 [0.86]

-0.077 [1.15]

-0.033 [0.42]

0.032 [0.96]

-0.087 [1.31]

-0.035 [0.69]

148

154

$-0.056 \quad$ [1.69]

size R-squared

$154 \quad 0.99$

$154 \quad 0.97$

$152 \quad 0.99$

$132 \quad 0.89$

$154 \quad 0.98$

$151 \quad 0.98$

$153 \quad 0.99$

$152 \quad 0.99$

$148 \quad 0.96$

$134 \quad 0.92$

$154 \quad 0.99$

$154 \quad 1$

$154 \quad 0.99$

$138 \quad 0.89$

$154 \quad 0.99$

$142 \quad 0.98$

$154 \quad 0.98$

$154 \quad 0.95$

$153 \quad 0.98$

$154 \quad 0.98$

$154 \quad 0.98$
0.093 [1.78]

Elementary admin and service occs

Notes:

(i) All equations are estimated using OLS. Each equation also includes lagged wages, lagged unemployment, age controls, skill controls, year dummies, and region dummies.

(ii) Notes (ii), (iii) and (v) Table 2. 


\section{BERR}

\section{Spatial Economics Research Centre (SERC)}

London School of Economics

Houghton Street

London WC2A 2AE

Tel: 02078523565

Fax: 02079556848

Web: www.spatialeconomics.ac.uk

SERC is an independent research centre funded by the Economic and Social Research Council (ESRC), Department for Business, Enterprise and Regulatory Reform (BERR), the Department for Communities and Local Government (CLG) and the Welsh Assembly Government. 